dents, not to undertake research. Yet everybody knows that the cost of mounting research projects is not small. Research grants do not flow readily to poorly equipped laboratories, people must spend time writing grant applications, the recruitment of technical staff (even when salaries are covered by grants) may be substantial and there is also heat and light to be paid for. In other words, there is an overhead that somebody must pay for. The US tradition is that, with greater or lesser grace, the grantmaking agencies eventually stump up. But now, at the instance of the federal government, they are jibbing (see page 361 ). What lessons should British universities, about to embark on the same path (see page 339), learn from the US experience?

One is that, despite general agreement about the propriety of the research overhead (curiously called an "indirect cost" in the United States), there is general disagreement about its proper size. Second, there can be no single percentage charge that will equitably cover all universities; the running costs of city-centre campuses may be unusually high, for example, but they may be the better able to recruit researchers on that account. Third, telling what charge is equitable cannot be determined by measurement, which would entail (among other things) knowing how academics spend their time. Fourth, the end-result must be a matter for negotiation, even bargaining, between the finance officers of grant-making agencies and university administrators (who will be tempted to charge the time they spend against the grants won by their academic colleagues).

It is too soon to tell whether the noises coming from the US Congress this past budget cycle mark a change in the rules or are simply a novel element in a familiar ritual, but the research enterprise as a whole has more to gain than to lose from a clearer understanding with the federal agencies. One danger, for example, is that ambitious university administrators may overspend on laboratory buildings in the expectation that their investments will eventually be returned as overhead charges, forgetting that in the process they deprive the system of funds that could be used for research itself, or for helping make good the general shortage of trained people. Seemly rules would help everybody, restrictive though they might seem.

The British dilemma is, as usual, at the other end of the spectrum. British universities are only just abandoning the convention that all universities are equal, and equally capable of carrying out excellent research. This development has been foisted on the system by two developments - the general pressure on recurrent budgets over the past decade, which has forced many institutions to spend on routine teaching and departmental functions funds that should have been spent on the infrastructure of research, and then, in the past five years, self-conscious speculation fostered by government agencies about the distinctions between "research" and "teaching" universities. It is hardly surprising that a canny government has seized the opportunity to say that some of the university budget should be transferred to the research councils, which should they pay overhead costs on some basis yet to be determined. The government will be able to boast of greater accountability, universities stroing in research may be marginally better off, but in British circumstances the general benefit is at best obscure.

Simple arithmetic shows the snags with the proposed arrangements.

For the past decade, it has been supposed that 30 per cent of recurrent university spending was devoted to the infrastructure of research, but that figure derives from the report by the late Sir Alec Merrison published in 1982 for which, even at the time, there was hardly any evidence. As some universities have devoted increasing proportions of their energy to teaching (there is nothing wrong with that, for that is their prime function), spending on the infrastructure of research has inevitably declined. And it shows. The result is that public support for academically based research has probably been declining even more quickly than can be told from the direct cost of research grants.

Yet curiously the government still counts 30 per cent of the cost of running universities in its annual summaries of public support for British science. British universities might usefully pick over this potential quarrel before they settle for what may otherwise be a meagre ration of overhead.

\section{Is this the eco-war?}

Spilled oil in the Persian Gulf is better than spilled blood on the sand, but there is probably that ahead.

IF the oil-spill in the Persian Gulf last week is said to be the worst ever, nobody should dissent. The president of Iraq has said from the beginning that foreign nationals now in Saudi Arabia would have to walk through fire if they were serious about reoccupying Kuwait; if United States aircraft had not set the off-shore terminal on fire by accident last week, there is every chance that fire would have been started deliberately instead. But even crude oil is flammable, so that a natural accident might well have done the trick. Wars have a tendency to evoke the unexpected; things go wrong.

If the oil-spill is described as a catastrophe, on the other hand, assent should be withheld, at least for the time being. It is true that some unique species are threatened by the southwards-spreading oil-slick, while it is sad to see (on television) so many cormorants at death's door. But we shall be lucky if the long-term consequences of the oilslick, for surface or bottom species, outlast the human problems that there will be when the present conflict comes to an end. It is remarkable that the people who are energetically placing floating booms to protect desalination plants along the east-facing coastline of Saudi Arabia should be giving so little thought to the persistent problems of the Middle East.

NATURE · VOL $349 \cdot 31$ JANUARY 1991 